\title{
強震を受ける座屈劣化型二層ブレース構造物の履歴吸収エネルギーと 層間変形集中に対する弾性柱材曲げ剛性の影響 STORY DRIFT CONCENTRATION AND HYSTERESIS ENERGY FOR TWO STORY BRACED FRAME WITH BUCKLING BRACES SUBJECTED TO STRONG MOTION
}

\author{
木村祥裕*, 松尾陽平**, 中澤泰 典*** \\ Yoshihiro KIMURA, Yohei MATSUO and Yasunori NAKAZAWA
}

\begin{abstract}
In our previous researches, it is shown that story drift concentration is restrained by columns in two braced frames with buckling-restrained braces. For the two story braced frames with buckled braces, it is possible for the column to distribute the shear force on each story over height and the story drift concentration may be restrained, if it keeps elastic. In this paper, the equations of the drift concentration factor for two story braced frames with buckled braces have been developed from the equilibrium conditions of the frames subjected to lateral force. This paper clarifies the mechanism of the two story braced frames and the relationship between the drift concentration factor and the ratio of column flexural stiffness. Finally, the drift concentration with seismic response analysis is estimated with the equation for static drift concentration.
\end{abstract}

Keywords: Drift Concentration Factor, Flexural Buckling of Braces, Lateral Deformation Demand, Ratio of Column Flexural Stiffness,

Pushover Analysis, Seismic Response Analysis

層間変形集中率，ブレース材曲げ座屈，塑性率，柱材曲げ岡性比，静的増分解析，地震応答解析

1. 序

一般に, ブレース付きラーメン構造は地震外力に対して強度抵抗型 の構造形式であり, ブレースの水平力の分担に応じて, 構造物の強度 を割り増す必要がある。例えば，純ブレース構造であればその割増率 は純ラーメン構造の 1.5 倍となる ${ }^{1)}$ 。しかし, 設計地震外力よりも大 きな荷重が作用し，ブレース材が座屈寸れば，層剛性は低下し，層間 変形角が増加する。そして, 変形の増加とともに保有水平耐力は低下 していくため, 特定層に層間変形が集中し, 構造物は倒壊する可能性 がある。そのため, ブレース付きラーメン架構における既往の研究 2), 3)では，構造物の保有水平耐力を明らかにしている。

二層鉄骨構造では，設計・施工性の観点から柱と梁を剛接合せず， ウェブのみでボルト接合する形式が多く, 純ブレース構造として設計 されている。通常, 低層ブレース構造物では, 引張ブレース構造が 多いものの，スパンが長く，階高が低い場合には十分な層剛性を 確保するために圧縮ブレースが適用されることもある。座屈劣化 型ブレースであっても，高さ方向に作用せん断力を適切に配分できる 十分な剛性と耐力をもつ柱材が架構内に配置されていれば, ブレース 材座屈後も特定層崩壊を防ぐことができる。

一方, ブレース材の降伏により層剛性が喪失することで生じる特定 層崩壊に対して, 著者らは主抵抗要素と二次抵抗要素で構成される二 層構造物と寸ることで, 主抵抗要素の二次剛性が 0 であっても二次抵 抗要素による応力再配分機構により層間変形集中の抑制が可能とな

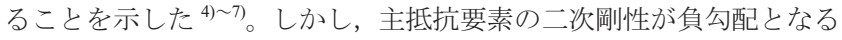
場合の二次抵抗要素による層間変形集中抑制効果について明らかに されていない。

また, 二層構造物の層間変形集中に及ぼす各種構造特性の影響を明

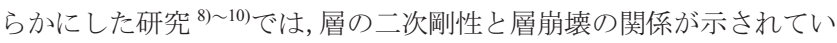
るが，正勾配をもつバイリニア型と仮定しており，座屈等の不安定現 象による負勾配の場合については明らかにされていない。

さらに, ブレース材が繰返し荷重を受ける場合，圧縮荷重を受けて 座屈を生じ耐力低下を生じた後, 引張荷重を受けるとピンチングを生 じるため, 弾塑性型の履歴性状を示寸座屈拘束ブレースに比べれば, エネルギー吸収性能は低くなることから ${ }^{11)}$, 12)，一方向載荷のみなら ず，繰返し履歴挙動についても考慮する必要がある。

本論文では, 主抵抗要素であるブレース材座屈後, 負勾配となる二 相系構造物の層間変形集中と, 二次抵抗要素である柱材による層間変 形集中抑制効果について明らかにする。水平外力を受ける構造物の静 的釣合いを仮定し，層間変形集中率の評価式を導く。ブレース材の座 屈後劣化勾配, 柱材曲げ剛性や架構の塑性率から架構の層間変形集中 率や柱材への作用モーメントを明らかにする。さらに, 構造物に損傷 を及ぼすレベルの強震が作用した場合に, 慣性力等の動的効果やブレ 一ス材の座屈後の履歴挙動が上記の構造特性と力学特性との関係に 及ぼす影響を検討する。
* 東北大学大学院工学研究科 教授 $\cdot$ 博士 (工学)

** 元 長崎大学大学院生産科学研究科 大学院生

*** 翔栄建築設計事務所
Prof., Graduate School of Engineering, Tohoku University, Dr. Eng. Graduate Student, Dept. of Structural Engineering, Nagasaki University

Shouei Architect \& Engineers Ltd. 


\section{2. 座屈劣化型二層ブレース構造物の層間変形と柱材作用モーメ ント}

座屈劣化型二層ブレース構造物を構成するブレース材の軸剛性, 軸耐力, 履歴挙動や柱材曲げ剛性と構造物の層間变形との関係を 釣合方程式により明らかにする。

\section{1 座屈劣化型二層ブレース構造物の層間変形及び柱材作用 モーメントに対する静的釣合いの仮定条件}

座屈劣化型二層ブレース構造物の崩壊機構を把握するために, 水平外力に対する架構の静的釣合いにより評価式を誘導する。そ の際，以下の仮定を用いる。

1) 二層ブレース構造物では，施工性の観点から梁材をウェブボ ルト接合のみで柱材に取り付ける場合が多いことから，梁材 及びブレース材両端はピン接合とする。梁材は床スラブを含 む合成梁とし, 梁材に作用する軸変形は無視するとともに, 塑性化や曲げ変形は生じないものとする。

2 ）通し柱材を弾性とし，通し柱材の柱脚をピン支持とする。二 層構造物の場合，柱脚に作用する軸力は小さく，また弾性範 囲であれば軸力による剛性低下が小さいことから，柱脚への 作用軸力による剛性低下を無視する。

3 ) 架構に作用寸る静的地震外力 $F_{i}$ を $A_{i}$ 分布 ${ }^{13)}$ により定めている。

4）ブレース材に作用するせん断力と座屈変形倍率の関係は図 2 に示すように，(a)の引張側ブレース材は完全弾塑性，(b)の圧 縮側ブレース材の座屈後の剛性は初期勾配の $\chi_{i}$ 倍の二次剛性 とし, 細長比が小さい $\lambda=40$ について文献 14), $\lambda=80,120,160$ では文献 15)をもとに算定する。細長比 $\lambda=60$ 以上の圧縮ブレ 一ス材が使用されることは少ないものの, 本論文では圧縮 ブレース材の座屈後, 挙動が架構の層間変形集中に及ぼす 影響を検討するために $\lambda=160$ までを対象としている。 $\chi_{i}$ は 負の值とし，座屈耐力は文献 14), 停留值は文献 15)により算 定している。停留值とは, 圧縮ブレース材が座屈後, 軸抵抗 力が一定となったときの值である。ブレース材全体の履歴挙 動は(a)と(b)を足し合わせた(c)のようになる。

5 ) 架構の高さ方向のせん断剛性比・耐力比を $\beta\left(=K_{2} / K_{1}=V_{f 2} / V_{f 1}\right)$ とする。また，架構におけるブレース材の層剛性の総和 $\Sigma E A_{b i} \cos ^{2} \theta / l$ に対する柱材の曲け剛性の総和 $\Sigma E I_{i} / h^{3}$ の比を柱材曲 げ剛性比 $\alpha$ と定義し，次式に示す。

$$
\alpha=\sum_{i=1}^{m} E I_{i} / h^{3} / \sum_{i=1}^{n} E A_{b i} \cos ^{2} \theta / l \quad(i \text { はスパン数 })
$$

ここで, $m$ は柱材の本数, $n$ はブレース材の本数である。また, 図 1 に示すように, $E I_{i}$ は柱材一本の曲げ剛性， $E A_{i}$ はブレース材 一本の軸剛性, $h$ は層高, $l$ はブレース材の材長, $\theta$ はブレース材 の傾きである。

$\alpha$ と実際の柱材断面との関係については, 例えば $\mathrm{H}$ 形鋼柱材が ブレース構面に対して弱軸方向に配置された場合， $\alpha$ は $0.001 〜 ~$ 0.05 程度, 強軸に配置された場合, $0.01 \sim 0.1$ 程度となる。また, 中程度から大口径鋼管柱材の場合， $\alpha$ は $0.1 \sim 1$ 程度となる。そし て，文献 16)，17)に示されるようなトラス柱材の場合， $\alpha \geqq 1$ と なる。

層間変形集中率恃架構頂部の水平変形 $\Delta_{2}$ を架構の高さ $H$ で除した 水平変形角 $\Delta_{2} / H$ に対して, 上下層のうち最大層間変形 $\delta_{\max }$ をその層の

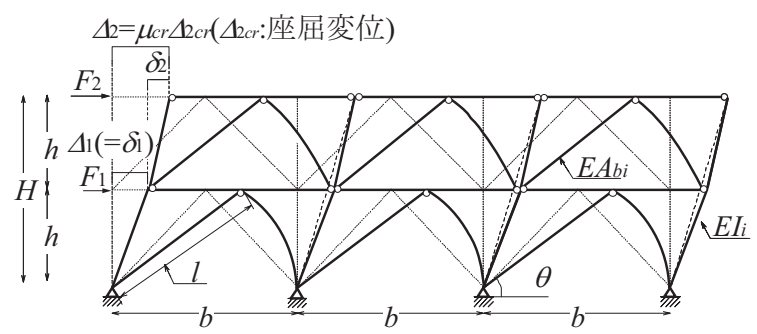

図 1 二層ブレース架構モデル

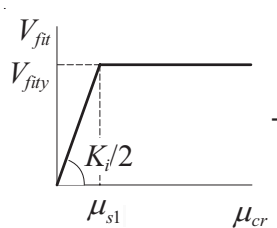

(a) 引張側ブレース

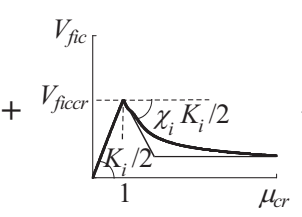

(b) 圧縮側ブレース

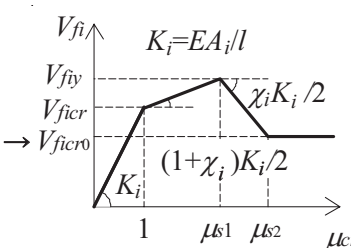

(c) ブレース全体
図 2 ブレース材に作用寸るせん断力と座屈変形倍率 $\mu_{c r}$

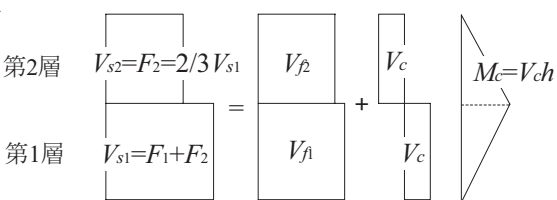

図 3 座屈劣化型二層ブレース架構の応力

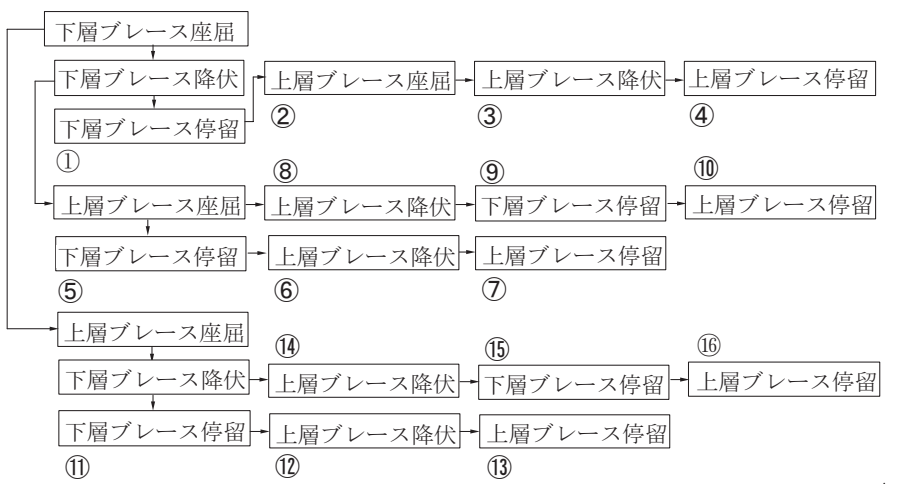

図 4 二層ブレース架構の崩壊プロセス

高さ $h$ で除した層せん断変形角 $\delta_{\text {max }} / h$ の比 $\left(\delta_{\text {max }} / h\right) /\left(\Delta_{2} / H\right)$ と定義する。

\section{2 静的釣り合いによる二層ブレース構造物の層間変形式及び 柱材作用モーメント式の誘導}

架構全体，ブレース架構部分，柱材のそれぞれの系に作用するせん 断力 $V_{s i}, V_{f i}, V_{c}(i=1,2)$ の関係及び柱材に作用寸るせん断力 $V_{c}$ と中 央変位 $\delta_{c}$ の関係は, 文献 4) と同様, 上述の仮定及び図 1〜3 より次式 となる。

$$
\begin{aligned}
& V_{s 1}=V_{f 1}+V_{c}, \quad V_{s 2}=\varphi V_{s 1}, \quad V_{s 2}=V_{f 2}-V_{c} \\
& V_{c}=\frac{E A_{b 1} b^{2}}{l^{3}} 3 \alpha \delta_{c-1}
\end{aligned}
$$

ここで, $\varphi\left(=A_{2} W_{2} / A_{1} W_{1}, A_{i}: A_{i}\right.$ 分布による係数, $W_{i}$ : 各層の重量 $)$ はせん断力比であり, $E A_{b 1}$ は下層のブレース材の軸剛性の和である

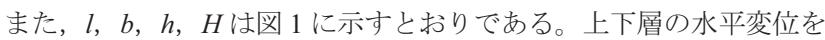
式で表すために, 各層のブレース材と柱材の変位が等しいという条件 を用いて層間変形集中率を求める。その際，架構の崩壊プロセスは図

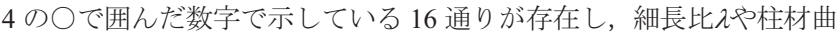


げ剛性比 $\alpha$ にって異なる。式は 4 種類に分かれており，層間変形は 2)，3)では増分形となり，それ以前の段階の層間変形を足し合わせ， そのときの層間変形集中率及び柱材作用モーメントを求める。その際, ブレース材が最初に座屈したときの架構頂部の水平変位を $\Delta_{2 c r}$ と定義 する。架構の座屈変形倍率 $\mu_{c r}$ とは, $\Delta_{2 c r}$ に対する架構頂部で生じてい る水平変位 $\Delta_{2}$ の割合である。また, ブレース材が最初に降伏したとき の架構頂部の水平変位を架構の降伏変位 $\Delta_{2 y}$ と定義する。架構の塑性 率 $\mu$ とは, $\Delta_{2 y}$ に対する架構頂部で生じている水平変位 $\Delta_{2}$ の割合である。 1) 下層のブレース材が座屈するまでの上下層変位 $\left(\mu_{c r} \leqq 1\right)$

$\mu_{c r} \leqq 1$ では，上下層の水平変位 $\delta_{1-1}, \Delta_{2-1}$ はブレース架構の上下層に 作用寸るせん断力 $V_{f 1-1}, V_{f 2-1}$ により次式で表される。

$$
\delta_{1-1}=\frac{l^{3}}{E A_{b 1} b^{2}} V_{f 1-1}, \quad \Delta_{2-1}=\delta_{1-1}+\delta_{2-1}=\frac{l^{3}}{E A_{b 1} b^{2}}\left(V_{f 1-1}+\frac{V_{f 2-1}}{\beta}\right)
$$

ここで， $\beta$ はブレース架構の高さ方向のせん断剛性・耐力比， $\delta_{2-1}$ は上層の層間変形である。下層圧縮側ブレース材が座屈したときのブ レース架構のせん断耐力を $V_{f l c r}$ とすると, (2) (4)式から上下層の水平 変位 $\delta_{1-1}, \Delta_{2-1}$ は次式で表される。

$$
\begin{aligned}
& \delta_{1-1}=\frac{l^{3}}{E A_{b 1} b^{2}} V_{f 1 c r}, \\
& \Delta_{2-1}=\left\{1+\frac{2 \varphi+3 \alpha(\varphi+1)}{2 \beta+3 \alpha(\varphi+1)}\right\} \frac{l^{3}}{E A_{b 1} b^{2}} V_{f 1 c r}=\Delta_{2 c r}
\end{aligned}
$$

柱材及び上層のブレース架構部分に作用するせん断力 $V_{c-1}, \quad V_{f-1}$ は 下層のブレース架構のせん断耐力 $V_{f l c r}$ により次式で表される。

$$
\begin{aligned}
& V_{c-1}=\frac{3 \alpha(\beta-\varphi)}{2 \beta+3 \alpha(\varphi+1)} V_{f 1 c r} \\
& V_{f 2-1}=\frac{\beta\{2 \varphi+3 \alpha(\varphi+1)\}}{2 \beta+3 \alpha(\varphi+1)} V_{f 1 c r}
\end{aligned}
$$

2) 下層ブレース材が座屈し耐力低下後, 下層ブレース材に作用する 軸力の停留開始までの上下層の水平変位

1)以降，すなわち図 2(c)に示すように下層ブレース材座屈後 $\left(\mu_{c r}>1\right)$ から下層のブレース材に作用する軸力の停留が始まるまでの架構全 体，ブレース架構部分，柱材のそれぞれの系に作用寸るせん断力増分 は(2), (3)式と同様, 次式で表される。

$$
\begin{aligned}
& V_{s 1-i j k}=V_{f 1-i j k}+V_{c-i j k}, \quad V_{s 2-i j k}=\varphi V_{s 1-i j k}, \quad V_{s 2-i j k}=V_{f 2-i j k}-V_{c-i j k} \\
& V_{c-i j k}=\frac{E A_{b 1} b^{2}}{l^{3}} 3 \alpha \delta_{c-i j k}
\end{aligned}
$$

ここで，iは崩壊プロセスの 1)〜4)において該当する段階を示す。 $j$ は下層ブレース材の変形状態であり,$j=1$ は下層ブレース材座屈後, $j=2$ は下層ブレース材降伏後を示寸。 $k$ は上層ブレース材の変形状態 であり, $k=1$ は上層ブレース材が弾性範囲, $k=2$ は上層ブレース材座 屈後, $k=3$ は上層ブレース材降伏後を示す。上下層の水平変位の増分 $\delta_{1-i j k}, \Delta_{2-i j k}$ は, ブレース架構の上下層に作用寸るせん断力の増分 $V_{f 1-i j k}$, $V_{\text {R-ijk }}$ により次式で表される。

$$
\begin{aligned}
& \delta_{1-i j k}=\frac{l^{3}}{E A_{b 1} b^{2} C_{j}} V_{f 1-i j k}, \\
& \Delta_{2-i j k}=\delta_{1-i j k}+\delta_{2-i j k}=\frac{l^{3}}{E A_{b 1} b^{2}}\left(\frac{V_{f 1-i j k}}{C_{j}}+\frac{V_{f 2-i j k}}{\beta D_{k}}\right)
\end{aligned}
$$

ここで， $C_{j}(j=1,2)$ は下層ブレース材の変形状態によって異なり,
圧縮ブレース材の座屈後は $C_{1}=\left(1+\chi_{1}\right) / 2$, 引張ブレース材の降伏後は $C_{2}=\chi_{1} / 2$ である。 $D_{k}(k=1 \sim 3)$ は上層ブレース材の変形状態によって異 なり, 弾性範囲では $D_{1}=1$, 圧縮ブレース材の座屈後は $D_{2}=\left(1+\chi_{2}\right) / 2$, 引張ブレース材の降伏後は $D_{3}=\chi_{2} / 2$ となる。ここで, $\chi_{i}(i=1,2)$ はブ レース材二次剛性比である。架構が座屈したときのブレース架構の 座屈せん断耐力 $V_{f l c r}$ により，(8) (10)式から上下層に作用するせん断 力の増分 $V_{f 1-i j k}, V_{f-i j k}$ は, 次式で表される。

$$
\begin{aligned}
& V_{f 1-i j k}=\frac{\left(\mu_{c r}-\mu_{s n}\right) C_{j}\left\{2 \beta D_{k}+3 \alpha(\varphi+1)\right\}}{2 \beta D_{k}+2 \varphi C_{j}+6 \alpha(\varphi+1)}\left\{1+\frac{2 \varphi+3 \alpha(\varphi+1)}{2 \beta+3 \alpha(\varphi+1)}\right\} V_{f 1 c r} \\
& V_{f 2-i j k}=\frac{\left(\mu_{c r}-\mu_{s n}\right) \beta D_{k}\left\{2 \varphi C_{j}+3 \alpha(\varphi+1)\right\}}{2 \beta D_{k}+2 \varphi C_{j}+6 \alpha(\varphi+1)}\left\{1+\frac{2 \varphi+3 \alpha(\varphi+1)}{2 \beta+3 \alpha(\varphi+1)}\right\} V_{f 1 c r}
\end{aligned}
$$

ここで, $\mu_{s n}$ は架構頂部の水平変形 $\Delta_{2-i j k}$ と下層ブレース材座屈時の架 構頂部の水平変形 $\Delta_{2 c r}$ の関係から(13)式で表すことができる。

$$
\mu_{s n}=\mu_{s(n-1)}+\frac{\Delta_{2-i j k}}{\Delta_{2 c r}}
$$

また，上下層の水平変位の増分 $\delta_{1-i j k}, \Delta_{2-i j k}$ は(10) (12)式より次式で 表される。

$$
\delta_{1-i j k}=\frac{\left(\mu_{c r}-\mu_{s n}\right)\left\{2 \beta D_{k}+3 \alpha(\varphi+1)\right\}}{2 \beta D_{k}+2 \varphi C_{j}+6 \alpha(\varphi+1)}\left\{1+\frac{2 \varphi+3 \alpha(\varphi+1)}{2 \beta+3 \alpha(\varphi+1)}\right\} \frac{l^{3}}{E A_{b 1} b^{2}} V_{f 1 c r}
$$

$$
\Delta_{2-i j k}=\left(\mu_{c r}-\mu_{s n}\right)\left\{1+\frac{2 \varphi+3 \alpha(\varphi+1)}{2 \beta+3 \alpha(\varphi+1)}\right\} \frac{l^{3}}{E A_{b 1} b^{2}} V_{f 1 c r}
$$

また, 柱材に作用寸るせん断力増分 $V_{c-\text { jik }}$ は下層ブレース架構の座屈 せん断耐力 $V_{f c r}$ により次式で表される。

$$
V_{c-i j k}=\frac{3 \alpha\left(\mu_{c r}-\mu_{s n}\right)\left(\beta D_{k}-\varphi C_{j}\right)}{2 \beta D_{k}+2 \varphi C_{j}+6 \alpha(\varphi+1)}\left\{1+\frac{2 \varphi+3 \alpha(\varphi+1)}{2 \beta+3 \alpha(\varphi+1)}\right\} V_{f 1 c r}
$$

3) 下層ブレース材に作用寸る軸力の停留開始以降, 上層ブレース材に 作用する軸力の停留開始までの上下層の水平変位

2)以降，すなわち図 2(c)に示すように下層ブレース材に作用する軸 力が停留し始めてからの架構全体, ブレース架構部分, 柱材のそれぞ れの系に作用するせん断力の増分は次式で表される。

$$
\begin{aligned}
& V_{s 1-i j k}=V_{c-i j k}, \quad V_{s 2-i j k}=\varphi V_{s 1-i j k}, \quad V_{s 2-i j k}=V_{f 2-i j k}-V_{c-i j k} \\
& V_{c-i j k}=\frac{E A_{b 1} b^{2}}{l^{3}} 3 \alpha \delta_{c-i j k}
\end{aligned}
$$

上下層の水平変位の増分 $\delta_{1-i j k}, \Delta_{2-i j k}$ は, 次式で表される。

$$
\begin{aligned}
& \delta_{1-i j k}=\Delta_{2-i j k}-\delta_{2-i j k}, \quad \delta_{2-i j k}=\frac{l^{3}}{E A_{b 2} b^{2} D_{k}} V_{f 2-i j k}, \\
& \Delta_{2-i j k}=\delta_{1-i j k}+\delta_{2-i j k}
\end{aligned}
$$

ここで, $E A_{b 2}$ は上層のブレース材の軸剛性の和である。架構が座屈 したときのブレース架構の座屈せん断耐力 $V_{f l c r}$ で表すと, (9), (17)式 から上層に作用するせん断力の増分 $V_{R-\text { - } j k}$ は次式となる。

$$
V_{f 2-i j k}=\frac{\left(\mu_{c r}-\mu_{s n}\right)\left\{3 \alpha(\varphi+1) \beta D_{k}\right\}}{2 \beta D_{k}+6 \alpha(\varphi+1)}\left\{1+\frac{2 \varphi+3 \alpha(\varphi+1)}{2 \beta+3 \alpha(\varphi+1)}\right\} V_{f 1 c r}
$$

また, 上層の層間変位の増分 $\delta_{2-i j k}$, 架構頂部の水平変位の増分 $\Delta_{2-i j k}$ は, (18), (19)式より次式となる。 
$\delta_{2-i j k}=\frac{\left(\mu_{c r}-\mu_{s n}\right)\{3 \alpha \beta(\varphi+1)\}}{2 \beta D_{k}+6 \alpha(\varphi+1)}\left\{1+\frac{2 \varphi+3 \alpha(\varphi+1)}{2 \beta+3 \alpha(\varphi+1)}\right\} \frac{l^{3}}{E A_{b 2} b^{2}} V_{f 1 c r}$

$$
\Delta_{2-i j k}=\left(\mu_{c r}-\mu_{s n}\right)\left\{1+\frac{2 \varphi+3 \alpha(\varphi+1)}{2 \beta+3 \alpha(\varphi+1)}\right\} \frac{l^{3}}{E A_{b 1} b^{2}} V_{f 1 c r}
$$

また，柱材に作用するせん断力増分 $V_{c-i j k}$ は，下層のブレース架構の 座屈せん断耐力 $V_{f l c r}$ により次式で表される。

$$
V_{c-i j k}=\frac{3 \alpha \beta\left(\mu_{c r}-\mu_{s n}\right) D_{k}}{2 \beta D_{k}+6 \alpha(\varphi+1)}\left\{1+\frac{2 \varphi+3 \alpha(\varphi+1)}{2 \beta+3 \alpha(\varphi+1)}\right\} V_{f 1 c r}
$$

4) 上下層ブレース材に作用する軸力の停留時における上下層変位

上下層ブレース材に作用する軸力が停留しており，架構全体，ブレ 一ス架構部分, 柱材に作用するせん断力は増減しない。架構全体, ブ レース架構, 柱材のそれぞれの系に作用するせん断力は次のようにな る。

$$
\begin{aligned}
& V_{s 2}=\varphi V_{s 1}, \quad V_{f 2}=\varphi V_{f 1}+(1+\varphi) V_{c} \\
& V_{c}=\frac{\beta-\varphi}{1+\varphi} V_{f 1}
\end{aligned}
$$

柱材の中央変位 $\delta_{c}$ は，(23)式を用いて次のように表される。

$\delta_{c}=\frac{l^{3}}{3 \alpha E A_{b 1} b^{2}} V_{c}=\frac{\beta-\varphi}{3 \alpha(1+\varphi)} \frac{l^{3}}{E A_{b 1} b^{2}} V_{f 1}$

上下層の層間変位 $\delta_{1}, \delta_{2}$ は $\delta_{c}$ を用いて次のように表される。

$$
\begin{aligned}
& \delta_{c}=\delta_{1}-\frac{\mu_{c r} \Delta_{2 c r}}{2}, \quad \delta_{1}=\frac{\mu_{c r} \Delta_{2 c r}}{2}+\delta_{c} \\
& \mu_{c r} \Delta_{2 c r}-\delta_{2}=\frac{\mu_{c r} \Delta_{2 c r}}{2}+\delta_{c}, \quad \delta_{2}=\frac{\mu_{c r} \Delta_{2 c r}}{2}-\delta_{c}
\end{aligned}
$$

以上より，上下層ブレース材に作用する軸力が停留しているとき， 各層の層間変位は次式によって求められる。

$$
\begin{aligned}
& \delta_{1}=\frac{\mu_{c r}}{2}\left\{1+\frac{2 \varphi+3 \alpha(\varphi+1)}{2 \beta+3 \alpha(\varphi+1)}\right\} \frac{l^{3}}{E A_{b 1} b^{2}} V_{f 1 c r}+\frac{\beta-\varphi}{3 \alpha(1+\varphi)} \frac{l^{3}}{E A_{b 1} b^{2}} V_{f 1} \\
& \delta_{2}=\frac{\mu_{c r}}{2}\left\{1+\frac{2 \varphi+3 \alpha(\varphi+1)}{2 \beta+3 \alpha(\varphi+1)}\right\} \frac{l^{3}}{E A_{b 1} b^{2}} V_{f 1 c r}-\frac{\beta-\varphi}{3 \alpha(1+\varphi)} \frac{l^{3}}{E A_{b 1} b^{2}} V_{f 1}
\end{aligned}
$$

ここで, 細長比が決まれば，(5)〜(7)式，(11), (12)式，(14)〜 (16) 式，(19) (21)式，(27)，(28)式中の $V_{f 1 c r}$ が定まり， $\Delta_{2 c r}$ 等を求めること ができる。また, 架構の塑性率と座屈変形倍率の関係は, 図 2(c)に示 される通り， $V_{f l y}$ と $V_{f 1 c r},\left(1+\chi_{i}\right) K_{i} / 2$ から求めることができる。

5) 層間変形集中率の算定

任意の架構の座屈変形倍率 $\mu_{c r}$ のときの各層の変位を求めるには, 崩壊プロセスにおいてどの段階であるかを調べる必要がある。そして， 各層の変位は各段階の変形量の総和として次のように表される。

$$
\begin{aligned}
& \delta_{1}=\sum_{i=1}^{N} \delta_{1-i j k} \\
& \Delta_{2}=\sum_{i=1}^{N} \Delta_{2-i j k}
\end{aligned}
$$

ここで, $N$ は 1)〜4)の崩壊プロセスにおいて, 該当する段階を示し ている。上式より層間変形集中率挝次式で表される。

$$
\gamma=\frac{\operatorname{MAX}\left(\left[\Delta_{2}-\delta_{1}\right], \delta_{1}\right) / h}{\Delta_{2} / H}
$$

また，各変形状態における柱材の作用モーメントは，(6), (16), (21) 式の上下層柱材の作用せん断力により次式で与えられる。

$$
M_{c}=\sum_{i=1}^{N} V_{c-i j k} h
$$

\section{3 単調載荷を受ける座屈劣化型二層ブレース構造物の層間変 形集中と柱材作用モーメント}

図 5 は, 構造物の層せん断力係数と各層の層間変形角との関係を示 している。縦軸は各層に作用する層せん断力 $V_{s i}$ を下層の総重量 $W_{1}$ で除したものであり，横軸は各層の層間変形角 $\delta_{i} / h$ である。数值解析 プログラムは繊維化塑性関節法による骨組構造解析システム FPHM ${ }^{18)}$ であり, $b=900 \mathrm{~cm}, h=360 \mathrm{~cm}$ とした図 1 のブレース架構を対象として いる。応力ひずみ関係はバイリニア型とし, 弾性係数 $E=205800 \mathrm{~N} / \mathrm{mm}^{2}$, ひずみ硬化勾配 $E_{s t}$ は $\mathrm{E} / 100$ とする。二層ブレース構造物では上下層 で同じ断面のブレース材を使用することが多いことから，解析モ

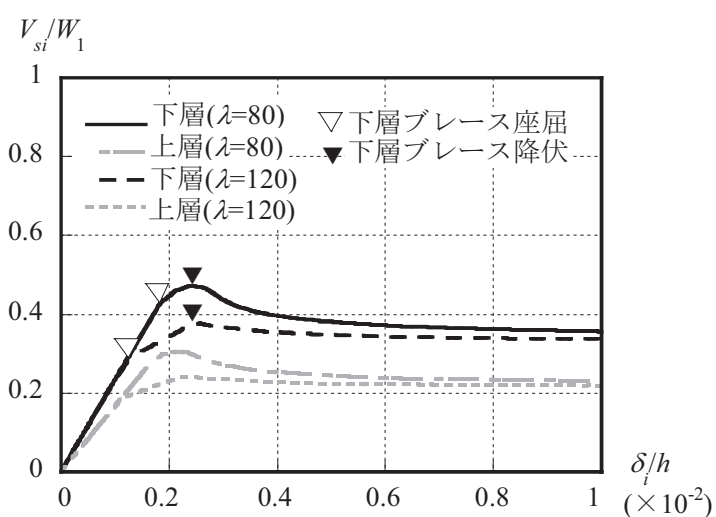

図 5 ベースシェア $V_{s i} / W_{1}$ と各層の層間変形角 $\delta_{i} / h(\alpha=1)$

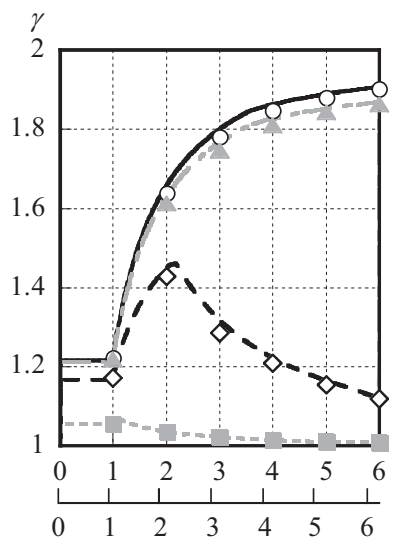

(a) $\lambda=40$

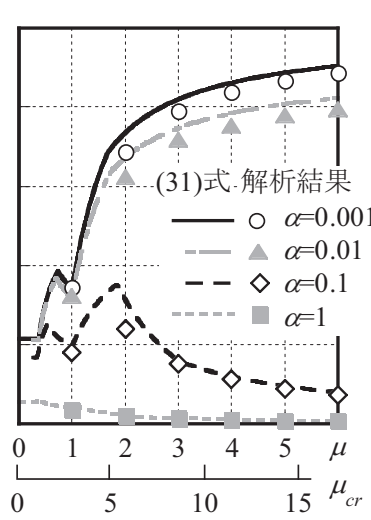

(b) $\lambda=160$
図 6 層間変形集中率 $\gamma$ 架構の塑性率 $\mu$, 座屈変形倍率 $\mu_{c r}$

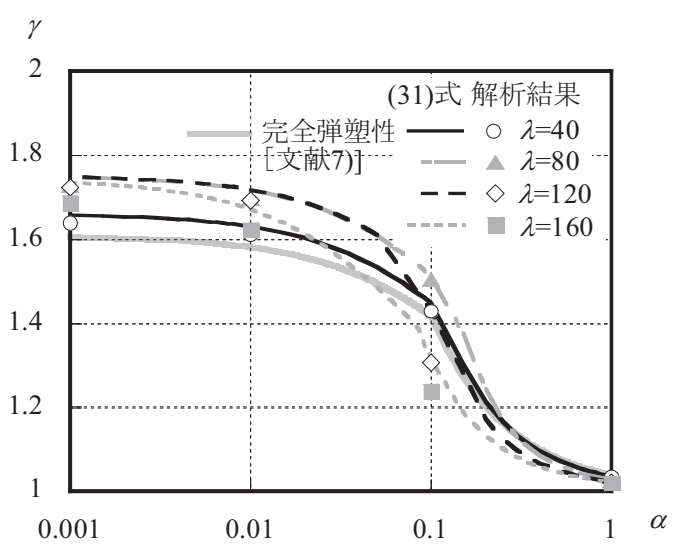

図 7 層間変形集中率 $\gamma$ と柱材曲げ剛性比 $\alpha(\mu=2)$ 
デルでは $\beta=1$ とし, 上下層ともにブレース材断面積 $A_{b}=6000 \mathrm{~mm}^{2}$, 降 伏応力 $\sigma_{y}=235 \mathrm{~N} / \mathrm{mm}^{2}$ とする。梁は合成梁を想定し, ブレースの圧縮, 引張により梁に大きな伸縮が生じないように剛とし，梁端はピン として柱に接合している。柱材は弾性とし， $\alpha=0.001 ， 0.01,0.1$, 1 となる断面二次モーメントを与えている。各層の質量は文献 4) と 同様，一スパンあたり 120tonf とする。田は下層圧縮側ブレース材の 座屈, 、湆引張側ブレース材の降伏した時点を示している。下層 ブレース材座屈時における層せん断力係数 $V_{s 1} / W_{1}$ は, $\lambda=80$ では 0.434 , $\lambda=120$ では 0.285 となっている。下層引張側ブレース材降伏時の $V_{s 1} / W$ は， $\lambda=80$ では $0.472, \lambda=120$ では 0.371 となっている。ブレース材の 細長比入が大きくなるにつれて, 最大層せん断力は低下している。

図 6 は, 架構の塑性率及び座屈変形倍率が層間変形集中率に及ぼす 影響を調べるため，(31)式及び数值解析結果を比較したものである。

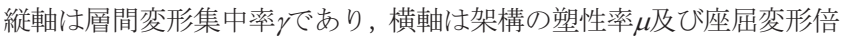
率 $\mu_{c r}$ である。各線は(31)式で示されるように，上下層の層間変形角の うち, 大きい方の值を架構頂部の水平変形角で除したものであり, 二 層構造物の場合 $1 \leqq \gamma \leqq 2$ の範囲となる。各プロットは数值解析結果で ある。(a) $\lambda=40$ の場合, $\alpha=0.001,0.01$ では下層ブレース材のみが座屈, 降伏を生じるため, 層間変形は下層に集中している。 $\alpha=0.1$ でも同様 に， $\mu=2.2\left(\mu_{c r}=2.3\right)$ 程度までは下層に層間変形が集中している。それ以 降は，上層ブレース材が座屈，降伏するため，層間変形集中率は低下 していく。 $\alpha=1$ では, ほぼ同時に上下層ブレース材が座屈, 降伏を生 じるため, 性 1 に収束していく。(b) $\lambda=160$ の場合, $\alpha=0.001,0.01$ では $\mu=0.7\left(\mu_{c r}=2\right)$ 程度, $\alpha=0.1$ では $\mu=0.5\left(\mu_{c r}=1.6\right)$ 程度で上層ブレース材 が座屈するため，恃低下していく。その後，下層ブレース材が降伏 し，下層の層間変形が大きくなるため，性増加していく。しかし， $\alpha=0.1$ については $\mu=1.8\left(\mu_{c r}=5.4\right)$ 程度で上層ブレース材が降伏するた め, 再び恃低下していく。 $\alpha=1$ では $\lambda=40$ の場合と同様, 束していく。

図 7 は, 柱材曲げ岡性比が架構の層間変形集中率に及ぼす影響を 調べるため, ブレース材の細長比をパラメータとして, (31)式と数值 解析結果を比較している。また，ブレース材の材料特性が完全弾塑 性の場合 7)を灰色実線で示している。縦軸は層間変形集中率とであり, 横軸は柱材曲げ剛性比 $\alpha$ であ。架構の塑性率 $\mu=2$ の場合を示してい る。 $\lambda=40$ の場合， $\alpha=0.001 \sim 0.1$ では下層ブレース材のみが座屈及び 降伏している状態であり， $\alpha$ が小さい範囲 $(\alpha=0.001 \sim 0.01)$ では $\gamma$ が約 1.65 程度となっている。 $\alpha=0.15 \sim 1$ では下層ブレース材が座屈，降伏 した後, 上層ブレース材が座屈及び降伏している状態となっている ため， 怟下していく。また， $\lambda=40$ と完全弾塑性の場合， $\gamma$ と $\alpha$ 関 係はほぼ等しい曲線となるが， $\alpha$ 等しいときの值は $\lambda=40$ の方が常 に高い。 $\lambda=80$ の場合， $\alpha=0.001 \sim 0.1$ では下層ブレース材が座屈及び 降伏した後，ブレース材に作用する軸力は停留しているため，下層 に大きな層間変形を生じ， $\alpha \geqq 0.05$ では他の細長比に比べて な值となる。 $\alpha=0.15 \sim 1$ では上下層ブレース材が座屈, 降伏を生じて いる。 $\alpha$ が大きいほど，上下層ブレース材の座屈，降伏の発生のタイ ムラグが小さくなるため, $、$ 急激に低下していく。 $\lambda=120$ の場合, $\alpha=0.001 \sim 0.045$ では $\lambda=80$ の場合と同様の崩壊機構であり， $の$ 值はほ ぼ同じとなる。 $\alpha \geqq 0.05$ では上層ブレース材が座屈を生じるため, $\lambda=80$ の場合に比べて $\gamma$ が低下している。 $\lambda=160$ では本論文で対象とし た全ての片いて下層ブレース材が座屈した後，上層ブレース材が
座屈している。 $\alpha \geqq 0.025$ で， $\lambda=40$ と $\lambda=160$ の場合で の大きさが逆転 しているのは, 図 6 から分かるように, $\mu=2$ で $\lambda=160$ の方が $\alpha$ の増加 による低減効果が大きいためである。

また，実際に，二層ブレース構造物に使用されうる柱断面とし て, 弱軸 $\mathrm{H}$ 形鋼 $(\mathrm{H}-400 \times 400 \times 15 \times 15)$, 強軸 $\mathrm{H}$ 形鋼 $(\mathrm{H}-400 \times 400 \times 15 \times 15)$ ，円形鋼管（○-400×7.9）を選定すると，柱 材の曲げ剛性比は $\alpha=0.011 ， 0.032 ， 0.013$ となる。低層ブレース構 造物には，弱軸 $\mathrm{H}$ 形鋼を使用することが多いことから，通常の構 造物では最下層の層間変形集中を防ぐことは難しい。層間変形集 中を抑制するためには強軸 $\mathrm{H}$ 形鋼の使用等が考えられる。

図 8 は, 架構の塑性率及び座屈変形倍率が柱材作用モーメントに及 ぼす影響を調べるため，柱材曲げ剛性比 $\alpha$ をパラメータとして，(32) 式及び数值解析結果を比較したものである。縦軸は, 柱材作用モーメ ント $M_{c}$ を下層の降伏せん断耐力に階高を乗じた $V_{f 1} h$ で除したもので ある。横軸は, 架構の塑性率 $\mu$ 及び座屈変形倍率 $\mu_{c r}$ である。(a) $\lambda=40$ の場合, 下層ブレース材座屈後, $\mu=1 \quad\left(\mu_{c r}=1 \sim 1.05\right)$ で下層が降伏し ている。 $\alpha$ が大きいほど下層ブレース材が座屈, 降伏後に柱材作用モ 一メントは急激に増加している。しかし， $\alpha=1$ では $\mu=1.08 \quad\left(\mu_{c r}=1.13\right)$ 程度, $\alpha=0.1$ では $\mu=2.06 （ \mu_{c r}=2.15 ）$ 程度で上層ブレース材が座屈し, 柱材作用モーメントは緩やかに増加する。その後， $\alpha=1$ では $\mu=1.13$ $\left(\mu_{c r}=1.18\right)$ 程度， $\alpha=0.1$ では $\mu=2.18 \quad\left(\mu_{c r}=2.27\right)$ 程度で上層ブレース 材が降伏し， $M_{c}$ は低下していく。 (b) $\lambda=160$ の場合， $\lambda=40$ の場合に

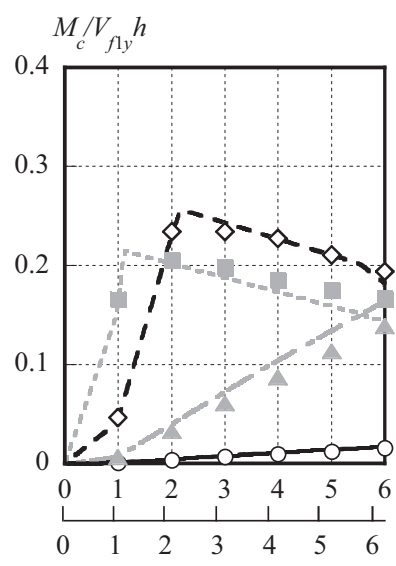

(a) $\lambda=40$

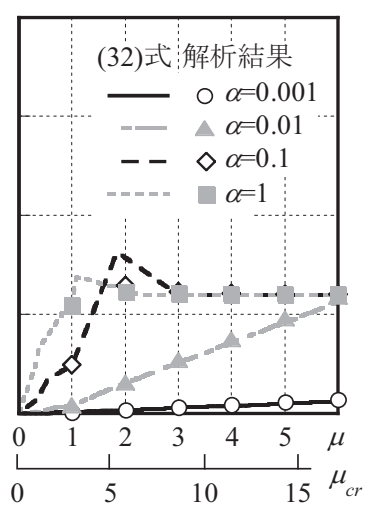

(b) $\lambda=160$
図 8 柱材作用モーメント $M_{c} / V_{f 1 y} h$ と架構の塑性率 $\mu$, 座屈変形倍率 $\mu_{c r}$

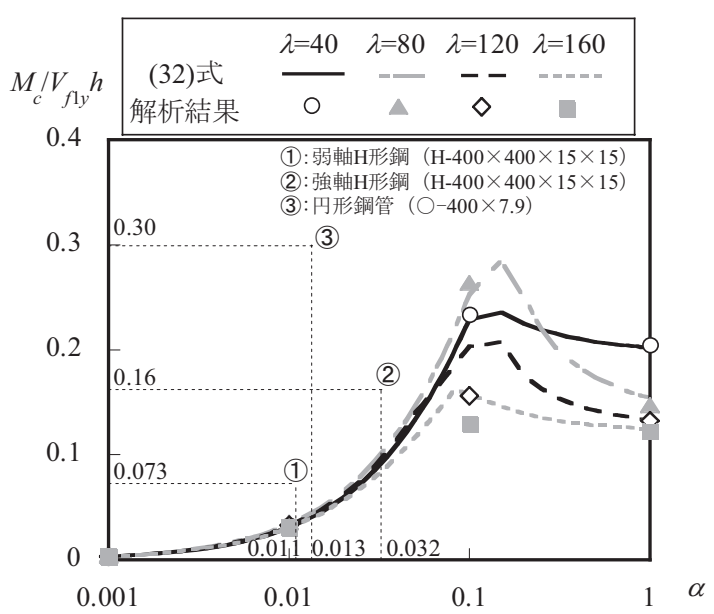

図 9 柱材作用モーメント $M_{c} / V_{f 1 y} h$ と柱材曲げ剛性比 $\alpha \quad(\mu=2)$ 
比べて $M_{c}$ の急激な上昇は見られない。これは, ブレース材の座屈耐 力が低く, 下層ブレース材が座屈した後, 上層にせん断力が再配分さ れ，上層がすぐに座屈することから，柱材に作用するせん断力は増加 しないためである。 $\alpha=1$ では $\mu=1.09\left(\mu_{c r}=3.28\right)$ 程度, $\alpha=0.1$ では $\mu=1.84$ $\left(\mu_{c r}=5.35\right)$ 程度で上層が降伏し， $M_{c}$ は低下していく。

図 9 は, 柱材曲げ剛性比が柱材作用モーメントに及ぼす影響を調べ るため, ブレース材の細長比入をパラメータとして, (32)式と数值解析 結果を比較している。また, ブレース材の材料特性が完全弾塑性の場 合7)を線で示している。縦軸は, 柱材作用モーメント $M_{c}$ を下層の降伏 せん断耐力に階高を乗じた $V_{f l} h$ で除したものであり, 横軸は柱材曲げ 剛性比 $\alpha$ である。また，柱材を弱軸 $\mathrm{H}$ 形鋼（H-400×400×15×15），

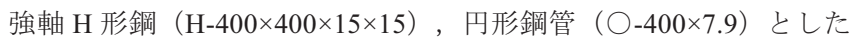
場合の柱材曲げ岡性と柱材曲げ耐力の関係を(1), (2), (3)として点線 で示している。それぞれの柱梁曲げ剛性比は $\alpha=0.011,0.032,0.013$ である。降伏応力度は SN400（STK400）相当として $235 \mathrm{~N} / \mathrm{mm}^{2}$ と して曲げ耐力を求めている。 $\lambda=40$ の場合, $\alpha=0.001 \sim 0.1$ では下層ブ レース材が座屈, 降伏した状態であり, $\alpha$ 増加に伴い, $M_{c}$ は増加し ていく。しかし, $\alpha=0.15$ 以上では下層ブレース材が座屈, 降伏後, 上 層ブレース材も同椂に座屈, 降伏を生じるため, $\alpha$ が増加しても $M_{c}$ は 緩やかに低下し，約 0.2 に収束していく。 $\lambda=40$ と完全弾塑性の場合， $\alpha<0.1$ では $M_{c}$ と $\alpha$ の関係はほぼ等しい曲線となるが， $\alpha \geqq 0.1$ では完全 弾塑性の場合はブレース材の降伏により柱材への作用せん断力の増分 がないために, 一定の值になる。 $\lambda=80$ の場合, 最大柱材作用モーメン 卜は, $\lambda=40$ の場合よりも高く, $\alpha=0.15$ で $M_{c}=0.29$ 程度に達し, その後, 急激に低下していく。これは, $\lambda=40$ の場合と同様， $\alpha=0.15$ 以上では 上層ブレース材も座屈，降伏を生じているため， $M_{c}$ は低下していく。 $\lambda=120$ の場合, $\alpha=0.001 \sim 0.045$ では下層ブレース材のみ座屈, 降伏, 作用する軸力が停留し, $\alpha=0.05 \sim 0.1$ ではそれらに加えて上層ブレース 材が座屈している。しかし， $\alpha=0.001 \sim 0.1$ の範囲では $\alpha$ 大゙大きなる ほど $M_{c}$ は増加しており, 上層ブレース材の座屈は $M_{c}$ の増減に大きな 影響を与えていない。 $\alpha=0.15$ 以上では上下層ブレース材が交互に座屈, 降伏を生じるため $M_{c}$ は低下していく。 $\lambda=160$ の場合, 全ての $\alpha$ 範囲 で上下層ブレース材が交互に座屈した後, 下層ブレース材が降伏して
いる。 $\alpha=0.085 \sim 0.095$ では, その後, 下層ブレース材に作用する軸力 が停留し，上層ブレース材が降伏している。 $\alpha=0.1$ 以上では上下層ブ レース材が交互に座屈，降伏を生じる。そのため $\alpha=0.085$ 以上では $M_{c}$ は低下していく。また，(1)（3)の柱断面を用いたとき，それぞれの 柱材曲げ岡性比に対して, 柱材作用モーメントは柱材曲げ耐力を以 下であるため, SN400 相当であれば柱材は弾性保持できる。

\section{4 繰り返し荷重を受ける座屈劣化型二層ブレース構造物の 層間変形集中}

図 10 に繰り返し荷重を受ける座屈劣化型二層ブレース架構のブレ 一ス材及び柱材の履歴曲線を示す。縦軸は, 上下層ブレース材及び柱 材に作用寸るせん断力 $V_{f 2}, V_{f 1}, V_{c}$, 横軸は架構の座屈変形倍率 $\mu_{c r}$ で ある。各図は $\lambda=40, \alpha=0.01$ の場合である。文献 19)に示されているよ うに, 実際の地震動による架構の振幅は漸増型に近いため, 変位漸増 型の載荷とした。変位増分を座屈変形倍率 $\mu_{c r}= \pm 2, \pm 4, \pm 6$ として いる。(e), (f)の下層ブレース材では, 右側ブレース材が座屈し, 左側 ブレース材が降伏点に達した後， $\mu_{c r}=2$ 一と至る。そこから除荷し, $\mu_{c r}=-2$ まで載荷すると, 左側ブレース材が座屈した後, 右側ブレース 材は降伏点に達している。その後, $\mu_{c r}= \pm 4, \pm 6$ まで載荷した場合も 同様である。しかし，(a)，(b)に示すように，上層ブレース材は座屈 や降伏を生じておらず, 架構の崩壊プロセスは図 4 の1)の状態であり, 下層のみの層間変形が増加していく。

図 11 は, 繰り返し回数の増加が架構の層間変形集中率に及ぼす影 響を示している。縦軸は層間変形集中率 $\gamma_{n}$, 横軸は繰り返し回数 $n$ で ある。プロットは $\mu_{c r}=2$ のときの各ループにおける值であり, 線は数 值解析結果をループ数， $\alpha, \delta_{1}, \delta_{2}$ で近似した次式より得られる。

$$
\begin{aligned}
& \gamma_{n}=\frac{\left\{1+\frac{n_{1}-n_{i}}{x-n_{1}} f(\alpha)\right\} 2 \delta_{1}}{\left\{1+\frac{n_{1}-n_{i}}{x-n_{1}} f(\alpha)\right\} \delta_{1}+\left\{1+\frac{n_{1}-n_{i}}{x-n_{1}} g(\alpha)\right\} \delta_{2}} \\
& f(\alpha)=\frac{1}{2}\left(1+e^{-10 \alpha}\right), \quad g(\alpha)=\frac{1}{2}\left(1-e^{-10 \alpha}\right)
\end{aligned}
$$

ここで， $\delta_{1} ， \delta_{2}$ は上下層の層間変位を示している。 $x$ は文献 14)より 求められるブレース材の非弹性座屈荷重 $P_{c r}$ と降伏荷重 $P_{v}$ を足し合わ
$V_{f 2 l}(\mathrm{kN})\left(\times 10^{4}\right)$

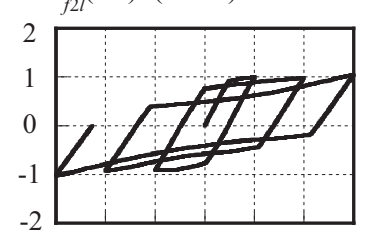

（a）上層左側ブレース $V_{f 1 l}(\mathrm{kN})\left(\times 10^{4}\right)$

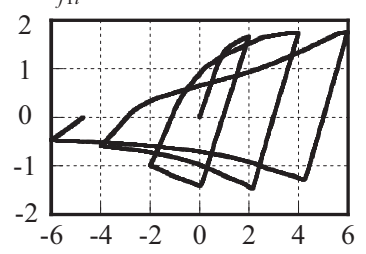

（e）下層左側ブレース

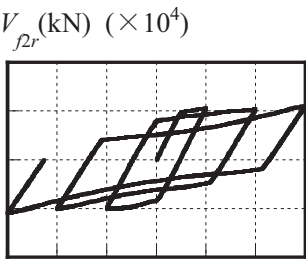

（b）上層右側ブレース $V_{f l r}(\mathrm{kN})\left(\times 10^{4}\right)$

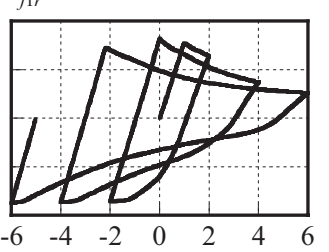

（f）下層右側ブレース
$V_{f(\mathrm{kN})}\left(\times 10^{4}\right)$

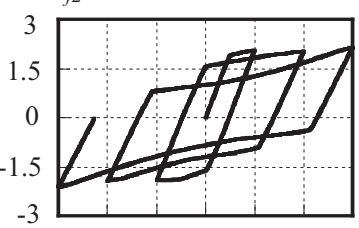

（c）上層両ブレース
$V_{f 1}(\mathrm{kN}) \quad\left(\times 10^{4}\right)$

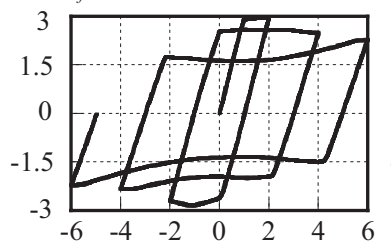

（g）下層両ブレース
$V(\mathrm{kN}) \quad\left(\times 10^{3}\right)$

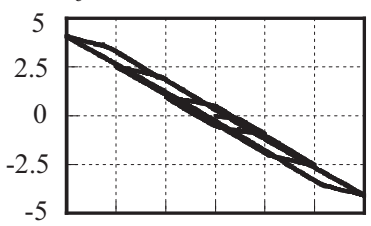

（d）上層柱材

$V(\mathrm{kN}) \quad\left(\times 10^{3}\right)$

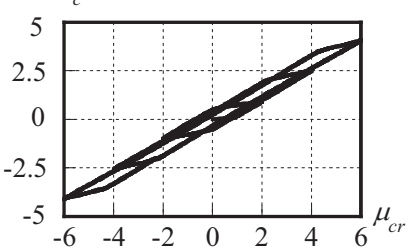

（h）下層柱材

図 10 上下層ブレース材及び柱材に作用するせん断力 $V_{f 2}, V_{f 1}, V_{c}$ と座屈変形倍率 $\mu_{c r} \quad(\lambda=40, \quad \alpha=0.01)$ 
せて降伏荷重 $P_{y}$ で除したものである。また， $n_{i}$ は文献 12)の(1) (6) 式より導出したブレース材の各ループにおける圧縮側, 引張側の荷重 を足し合わせたものである。 $f(\alpha)$ と $g(\alpha)$ は $\delta_{1}, \delta_{2}$ に対する $\alpha$ 影響因子 として(34)式とした。(a) $\lambda=40$ の場合， $\alpha=0.001 ， 0.01$ では $n=1$ に比心゙ て $n=3$ の $\gamma_{n}$ は約 $10 \%$, 同じく $\alpha=0.1$ では約 7\%増加し， $\alpha=1$ ではほと んど変化しない。これは, $\alpha$ 小゙さいほど下層のせん断耐力が低下し,

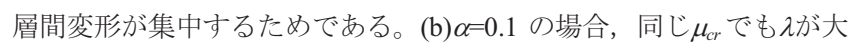
きいほど耐力の低下を生じ, 繰り返し回数の増加による $\gamma_{n}$ の増加率は 大きくなる。

図 12 に上下層ブレース材の履歴吸収エネルギー $E$ と柱材曲げ岡性 比 $\alpha$ との関係について示す。履歴吸収エネルギー $E$ は, 図 10 のような 繰り返し載荷における各ループの総面積である。その際, $V_{f i} / N_{y} \cos \theta$ $\sim \delta_{i} / \delta_{i y}$ 関係から算出した。 $N_{y} \cos \theta$ はブレース材降伏時におけるブレー ス架構部分のせん断耐力である。 $\delta_{i y}$ はブレース材降伏時の層間変形で ある。

(a) $\lambda=40$, (b) $\lambda=160$ の場合ともに $\alpha$ 小ざいと, 下層のみにエネル ギーが集中し，上層でエネルギーを吸収しない。しかし， $\alpha$ 大きく なると，上層の負担するエネルギーが増加する。特に $\alpha=1$ では上下層 でのエネルギー分担率はほぼ等しくなる。 $\alpha$ が大きいほど，同じ座屈 変形倍率での架構全体のエネルギー吸収は高く, (a) $\lambda=40$, (b) $\lambda=160$ の場合ともに, $\alpha=1$ の上下層のエネルギー吸収の総和は $\alpha=0.001$ の 1.3 倍程度になっており，柱材により高さ方向に負担エネルギーを分散さ せることで架構は効率良くエネルギー吸収できることが示されてい る。また， $\lambda=40$ の場合， $\lambda=160$ の場合に比べて履歴吸収エネルギーが 7〜8 倍となっている。

\section{3 . 座屈劣化型二層ブレース構造物の地震応答性状}

本章では，前章における静的地震外力の釣合いより得られた層間 変形集中及び柱材作用モーメントを元に, 架構が損傷を生じるレベ ルの強震を受ける場合の動的効果を検討する。

\section{1 二層ブレース構造物の動的応答解析概要}

2 章で誘導された層間変形集中率式及び柱材作用モーメントの算定 式 [(31)式，(32)式］と複数の観測地震波(EL Centro 1940 NS/ EW, Hachinohe 1968 NS/ EW, Kobe 1995 NS/ EW, Taft 1952 NS/ EW, Tohoku 1978 NS/ EW)による地震応答解析結果を比較し, これらの算定式の適 用の可能性を検証する。解析に用いる架構モデルは図 1 と同様の形状 とする。また, 表 1 は架構の固有周期 $T$ と, $\alpha=0$ を基準としたときの 割合 $T / T_{0}$ である。固有周期の差が最大となる $\alpha=1$ の場合でも, $5 \%$ 以内 であり， $\alpha$ 変化に伴う固有周期の減少が応答に与える影響は, 小さい ものと考えられる。数值解析には繊維化塑性関節法 ${ }^{18)}$ を基礎にした動 的解析コード(FPHM-D $)^{20)}$ を使用し, 時間成分刻みは $1 / 500$ 秒である。

\section{2 二層ブレース構造物の動的応答性状に対する弾性柱材の効} 果

図 13 に弾性柱材を有する二層ブレース架構において最大座屈変形 倍率を生じる下層での応答変位時刻歴を示す。地震波は Taft $1952 \mathrm{EW}$ である。縦軸は下層での層間変形角 $\delta_{1} / h$ 及び座屈変形倍率 $\mu_{c r 1}$ である。 (a)は $\lambda=120, \alpha=0.01 ，(\mathrm{~b}) は \lambda=160, \alpha=0.01 ，(\mathrm{c}) は \lambda=160, \alpha=1$ について

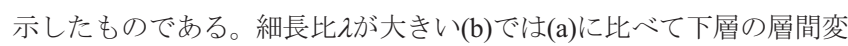
形角が大きくなっている。これは，入が大きいほどブレース材の座屈 耐力が低く，下層に大きな変形集中を生じているためである。また，

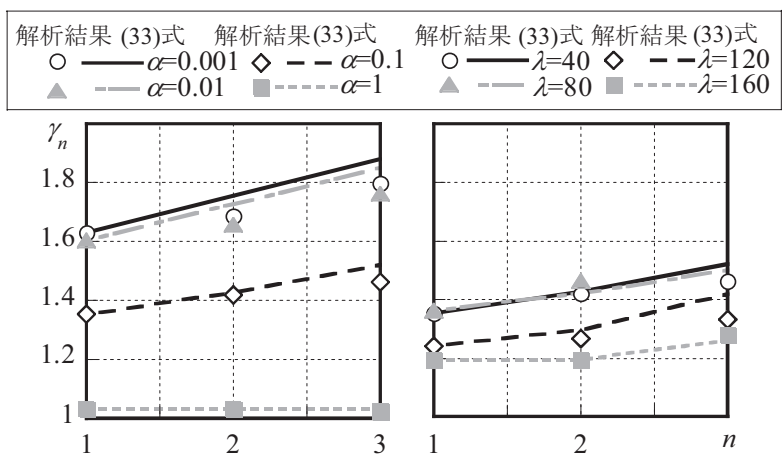

解析結果 (33)式 解析結果 (33)式

(a) $\lambda=40$

(b) $\alpha=0.1$

図 11 層間変形集中率 $\gamma$ と繰り返し回数 $n\left(\mu_{c r}=2\right)$

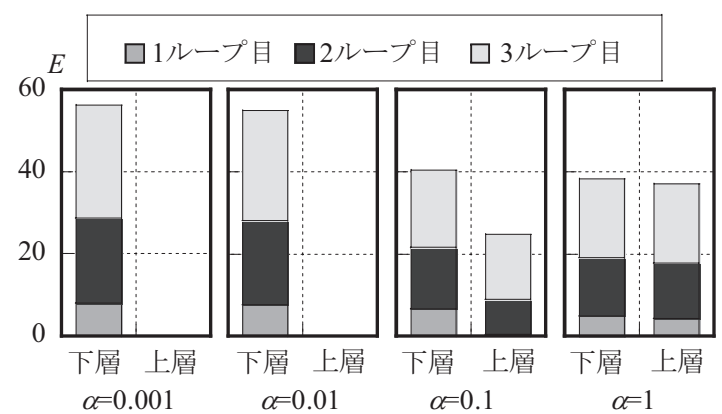

(a) $\lambda=40$

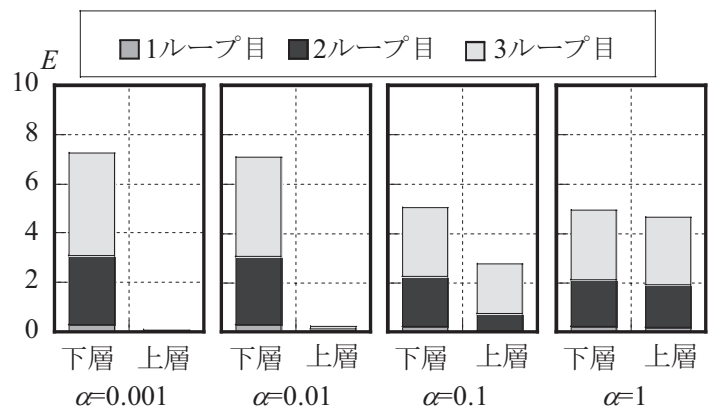

(b) $\lambda=160$

図 12 上下層ブレース材の履歴吸収エネルギー $E$ と柱材曲げ剛性比 $\alpha$

表 1 架構の固有周期に対する柱材曲げ岡性の影響

\begin{tabular}{|c|c|c|c|c|c|}
\hline$\lambda$ & $\alpha$ & 0.001 & 0.01 & 0.1 & 1 \\
\hline \multirow{2}{*}{40} & $T$ & 0.222 & 0.222 & 0.217 & 0.217 \\
\cline { 2 - 6 } & $T / T_{0}$ & 1.000 & 1.000 & 0.978 & 0.978 \\
\hline \multirow{2}{*}{80} & $T$ & 0.227 & 0.222 & 0.222 & 0.217 \\
\cline { 2 - 6 } & $T / T_{0}$ & 1.000 & 0.978 & 0.978 & 0.957 \\
\hline \multirow{2}{*}{120} & $T$ & 0.227 & 0.222 & 0.222 & 0.217 \\
\cline { 2 - 6 } & $T / T_{0}$ & 1.000 & 0.978 & 0.978 & 0.957 \\
\hline \multirow{2}{*}{160} & $T$ & 0.227 & 0.222 & 0.222 & 0.217 \\
\cline { 2 - 6 } & $T / T_{0}$ & 1.000 & 0.978 & 0.978 & 0.957 \\
\hline
\end{tabular}

柱材曲げ岡性比 $\alpha$ が大きい(c)では(b) に比べて小さい層間変形角とな っている。これは， $\alpha$ が大きいほど，下層ブレース材の座屈・降伏後 に，柱材によって上層にせん断力が再配分されたためである。

\section{3 二層ブレース構造物の動的層間変形及び動的作用モーメン 卜評価}

図 15 に地震外力を受ける二層ブレース構造物の層間変形集中率を 静的釣合により誘導した(31)式と文献 12)より得られた (33)式と比較 している。また, 柱材作用モーメントを, 静的釣合により誘導した(32) 式と比較している。各プロットを細長比ごとに示している。また, ブ レース材の材料特性が完全弾塑性の場合 7)も×でプロットしている。 


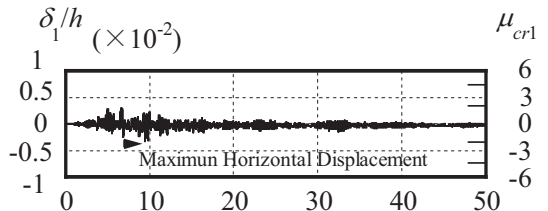

(a) $\lambda=120, \quad \alpha=0.01$

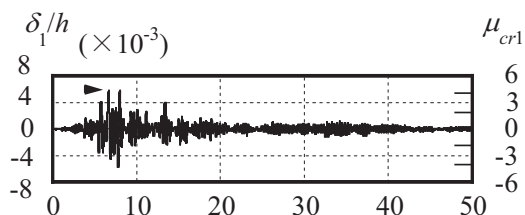

(b) $\lambda=160, \quad \alpha=0.01$

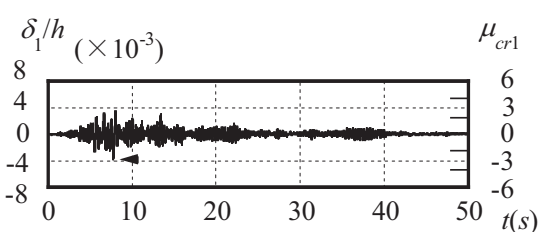

(c) $\lambda=160, \quad \alpha=1$

図 13 下層の応答変位時刻歴(Taft $1952 \mathrm{EW})$

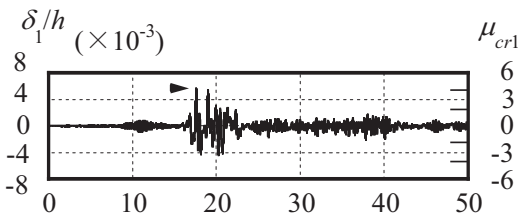

(a) $\lambda=160, \quad \alpha=0.01$

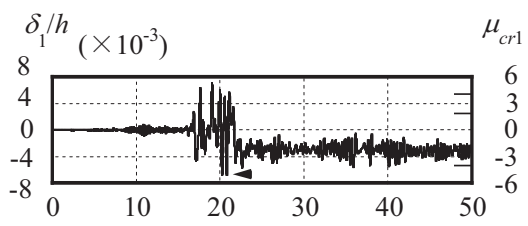

(b) $\lambda=160, \alpha=0.001$

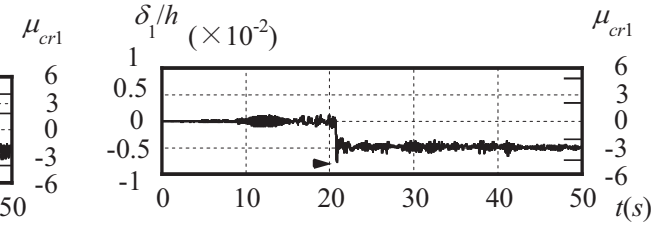

(c) $\lambda=120, \quad \alpha=0.01$

図 14 下層の応答変位時刻歴(Hachinohe $1968 \mathrm{EW})$

図 15(a)に動的層間変形集中率 $\gamma_{d}$ と静的層間变形集中率 $\gamma, \gamma_{n}$ の関 係を示す。縦軸は動的層間変形集中率 $\gamma_{d}$, 横軸は静的層間変形集中率 $\gamma, \gamma_{n}$ である。ここで, $\gamma$ は(31)式より求められる一方向載荷を受ける 場合， $\gamma_{n}$ は繰返し荷重の影響を考慮し，(33)式を適用した場合であ る。網掛けは 0.2 の範囲を示している。

(33)式の適用に際しては, 最初の塑性振幅が最大となる場合 [図 14(a)］を $n=1$, 最大変形に達する前に, 塑性変形を生じた場合, 漸増 型の塑性振幅回数を計算し, $n \geqq 2$ と寸る [図 14(b)]。本論文で対象と した解析モデルについては, 全て $n \leqq 3$ の範囲であった。式の適用前 では，特に $\lambda=120 ， 160$ では炕比べて $\gamma_{d}$ が大きくなっている。これは 2.4 節で述べたように, 繰り返し載荷を受けることによって $\mu_{c r}$ が等し い場合でも耐力低下を生じ, 細長比入が大きいほど層間変形集中率が 上昇したためである。式の適用後は， $\gamma_{d}$ と忙入の大きさによらずほぼ 20\%以内に収まっている。しかし, 図 14(c)のように, 大きな片振幅 となる応答を示した，地震波 Hachinohe $1968 \mathrm{EW}$ を受ける $\lambda=120$, $\alpha=0.01$ の場合，(33)式を適用しても $\gamma=1.44$ に対して $\gamma_{d}=1.8$ と大きくな っている。このように水平変形が片振幅の応答を示す地震波と架構の 組み合わせについては今後，検討する必要がある。

図 15(b)は柱材の動的最大作用モーメント $M_{c d}$ と動的最大モーメン 卜時の $\mu_{c r}$ に対応した(32)式の柱材作用モーメントであり, 縦軸, 横軸 をそれぞれ下層の降伏せん断耐力に階高を乗じ $V_{f 1 y} h$ で除したものと している。文献 7) と同様, $M_{c d}$ と $M_{c}$ は概ね一致しており, 動的作用モ ーメントについて(32)式により評価できる。ただし， $\lambda=40$ の場合では $M_{c} / V_{f y} h=0.21$ 前後, $\lambda=160$ の場合では $M_{c} / V_{f 1 y} h=0.13$ 前後にばらつきが 見られる。これは, 静的解析結果では $M_{c}$ が上記の值に達すると $\alpha$ の值 によらずほぼ一定となるものの, 動的解析結果では慣性力の影響によ り上記の 2 箇所で特に各層の最大作用せん断力が増幅・減少し, ばら つきが大きくなったものと思われる。

\section{4. 結}

本論文では, 座屈劣化型二層ブレース構造物を対象に, 構造物に 損傷を及ぼすレベルの強震が作用したとき，主抵抗要素にブレース 材，二次抵抗要素に弾性柱材を適用した架構について，ブレース材 の座屈及び降伏が層間変形集中率及び柱材作用モーメントに与える 影響について検討した。以下に得られた結論を示す。

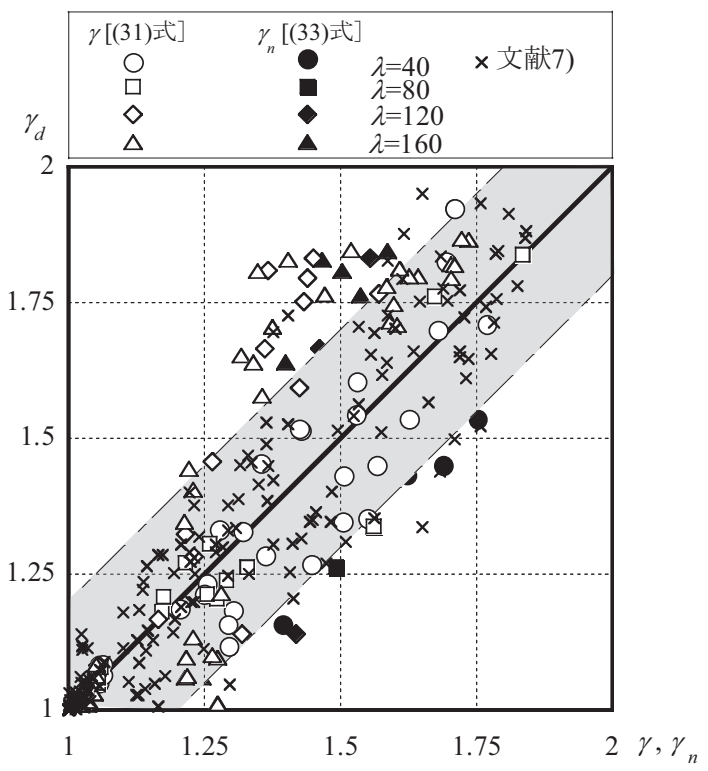

（a）動的層間変形集中率 $\gamma_{d}$ - 静的層間変形集中率 $\gamma, \gamma_{n}$

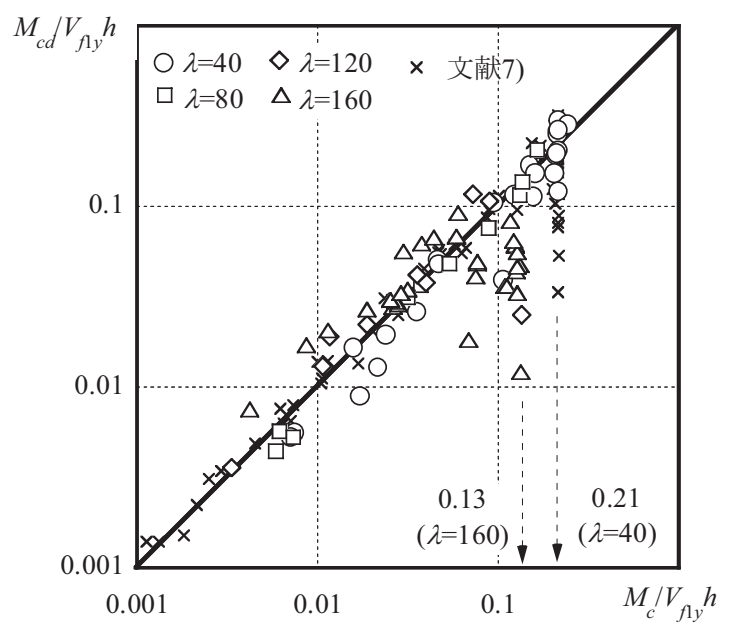

(b) 動的作用モーメント $M_{c d} / V_{f 1 y} h$ - 作用モーメント $M_{c} / V_{f l y} h$ 図 15 地震外力を受ける架構の動的応答評価

1)静的釣合いから誘導した二層ブレース構造物の層間変形集中率は, 架構の座屈変形倍率, 柱材曲げ剛性比とブレース材の材料特性の関 係より得られた(31)式で評価できる。ブレース細長比によらず, 
柱梁曲げ剛性比が $\alpha=0.1$ 以上になると, 架構の層間変形集中率は 急激に低下寸ることから，柱材による層間変形抑制効果が確認 された。

2)静的釣合いから誘導した二層ブレース構造物の柱材に作用するモ ーメントは, 架構の座屈変形倍率，柱材曲げ剛性比とブレース材の 材料特性の関係より得られた(32)式で評価できる。柱梁曲げ岡性比 が $\alpha=0.1$ で座屈変形倍率が $\mu_{c r}=2$ のとき, 柱材作用モーメントは最大 となり, 最下層の層せん断力に層高を乗じた值の $20 ３ 0 \%$ 程度に達 する。

3)繰り返し回数の増加に伴う架構の層間変形集中率の増加の割合は, 文献 12)より得られた各ループにおける同一変形時の荷重を用いた (33)式で概ね評価できる。ブレース材が繰返し荷重を受けるとき，柱 梁曲げ岡性比が小さい $\alpha=0.001,0.01$ では層間変形集中率は $10 \%$, $\alpha=0.1$ では 7\%ほど増加するが, 柱梁曲げ剛性比が大きい $\alpha=1$ ではほ とんど増加しない。

4)動的効果を考慮した架構の層間変形集中率は，(29)，(30)式より得 られた上下層の層間変形に(33)式のブレース材の繰返し振幅による 変形増加率を用いることで，誤差 $20 \%$ 以内で概社評価できる。動的 作用モーメントは，静的モーメントが停留する值以外では静的釣り 合いより誘導された(32)式で評価できる。すなわち, 架構に要求さ れる座屈変形倍率を定めることで, 設計上想定される地震動を受け る架構の層間変形集中率を予測することが可能となり, 層間変形集 中を抑制するための柱材断面を決定することができる。

\section{謝辞}

本研究は「国土交通省建設技術研究開発助成制度」及び「日本鉄 鋼連盟 鋼構造研究・教育助成」による成果である。ここに感謝 の意を表す。

\section{参考文献}

1) 国土交通省住宅局建築指導課，日本建築主事会議，日本建築センター：2001 年度版建築物の構造関係技術基淮解説書，2001

2) 五十嵐定義，井上一朗，小川厚治 : 鋼構造筋違付多層骨組の塑性設計に関す る研究，その 1 終局荷重時における筋違の水平力分担率の設定，日本建築 学会論文報告集，第263 号，pp.43-50，1978.1

3) 井上一朗，清水直樹：ブレース架構の保有水平耐力に関する考察，日本建築 学会構造系論文集, 第388 号, pp.59-69, 1988.6

4) 木村祥裕，グレゴリーマックレイ：二層ブレース架構における柱材の 力学性能の違いが架構の層間変形集中率に与える影響, 日本建築学会 構造系論文集，第 560 号，pp.189-195，2002.10

5) Gregory A. MacRae, Yoshihiro Kimura, Charles Roeder : Effect of Column Stiffness on Braced Frame Seismic Behavior, Jour. of Structural Engineering, ASCE, Vol.130, No.3 pp.381-391, 2004.3

6) 木村祥裕: 損傷制御型二層ブレース構造物の層間変形集中率に対する弾性柱材 の抑制効果，日本建築学会構造系論文集，第 612 号，pp187～pp.195，2007.2

7) 木村祥裕，御幡結，中澤泰典：強震を受ける損傷制御型二層ブレース 構造物の層間変形集中に対するブレース材の二次剛性の影響, 日本建 築学会構造系論文集, 第 75 巻, 第 651 号, pp997 pp.1004, 2010.5

8) 川島和彦, A.Macrae，G.，星隈順一，長屋和宏 : 残留変位応答スペク トルの提案とその適用，土木学会論文集，No.501/I-2,pp183-192,1995

9) 中島正愛, 三谷貴志, 辻文三 : 第二剛性比の高いバイリニア系のエネ ルギー入力・消費特性，構造工学論文集，vol. 42B，pp.59～68，1996.3

10) 日比野陽，市之瀬敏勝：強震を受ける 2 層鋼構造建物で塑性変形が卓 越する層を予測する方法，日本建築学会構造系論文集，第 606 号，pp105～ pp.111, 2006.8

11) 柴田道生，中村武，若林實：鉄骨筋違の履歴特性の定式化(その 1 定
式化関数の誘導), 日本建築学会論文報告集, 第 316 号, pp.18-24, 1982.6 12) 柴田道生, 若林實 : 鉄骨筋違の履歴特性の定式化(その 2 応答解析一 の適用)，日本建築学会論文報告集，第 320 号，pp.29-35，1982.10

13) 国土交通省住宅局建築指導課, 日本建築主事会議, 日本建築センター : 2001 年 度版建築物の構造関係技術基淮解説書, 2001

14）日本建築学会 : 鋼構造座屈設計指針 1996

15) Paris, P.C.: Limit Design of Columns, Journal of the Aeronautical Science, 1954.1.

16) Tremblay, R:Achieving a Stable Inelastic Seismic Stability of Concentrically Braced Steel Frames, Engineering Jour. AISC, Vol.40, No.2, pp.111 129, 2003

17) 多賀謙蔵，加登美喜子，徳田幸弘，鶴田潤，和田章 : ダンパー効率を高めたパ ッシブ制震構造における構造計画上の留意点と実用性, パッシブ制振構造シン ポジウム 2004, pp.105〜112, 2004.11

18) M.Shugyo : Elastoplastic large deflection analysis of 3D steel frames, Jour. of Struct. Engrg., ASCE, Vol.129, No.9, pp.1259-1267, 2003.9

19）井上一朗：塑性歪履歴を受ける鋼構造部材の耐震性能判定に関する一 考察，構造工学論文集，Vol.41B，pp621-629，1995.3

20) 修行稔, 島津勝, 木村まい: RC スラブの合成効果を考慮した鋼骨組 の動的立体解析，鋼構造年次論文報告集，pp621-626，2009.11

21) 日本建築学会：建築耐震設計における保有耐力と変形性能(1990), 1990.10

22) 穂積秀雄, 牧野行伸, 坂井誠, 平野道勝 : 鋼筋かい材の弾塑性性状お よび座屈後破断に関寸る実験研究 I，その 1 研究計画と素材試験, 日本建築学会大会学術講演梗概集，C-1，pp.379-380，1995.8

23) 穂積秀雄, 牧野行伸, 坂井誠, 平野道勝 : 鋼筋かい材の弾塑性性状お よび座屈後破断に関する実験研究 I, その 2 実験計画と結果, 日本 建築学会大会学術講演梗概集，C-1，pp.381-382，1995.8

\section{付録}

本論文の数值解析に用いている繊維化塑性関節法による骨組構造 解析システム $\mathrm{FPHM}^{18)}$ と実験結果 ${ }^{23)}$ との比較を以下に示す。断面形状 及び材料特性 ${ }^{22)}$ は付表 1 の通りである。ひずみ硬化勾配 $E_{s t}$ は $E / 100$ とする。部材の材長は $1220 \mathrm{~mm}$ とし, 細長比入は 40 である。部材の 両端はピン支持とし，初期不整は $l / 1000 \sin (\pi x / l)$ で与えている。付図 1 に繰り返し載荷を行った結果を示す。縦軸は荷重 $P$ を降伏荷重 $P_{y}$ で除したものであり, 横軸は部材軸方向変位 $\delta$ を降伏変位 $\delta y$ で除した ものである。解析結果は文献 23)の実験結果に比べて, 引張最大荷重 が低いものの, 圧縮側では概ね対応しており, 解析プログラムの妥 当性が示されている。

付表 1 断面形状及び材料特性

\begin{tabular}{|c|c|c|}
\hline 断面形状 & $\sigma_{y}\left(\mathrm{~N} / \mathrm{mm}^{2}\right)$ & $E\left(\mathrm{~N} / \mathrm{mm}^{2}\right)$ \\
\hline $\mathrm{H}-125 \times 125 \times 6 \times 6$ & 324 & 212000 \\
\hline
\end{tabular}

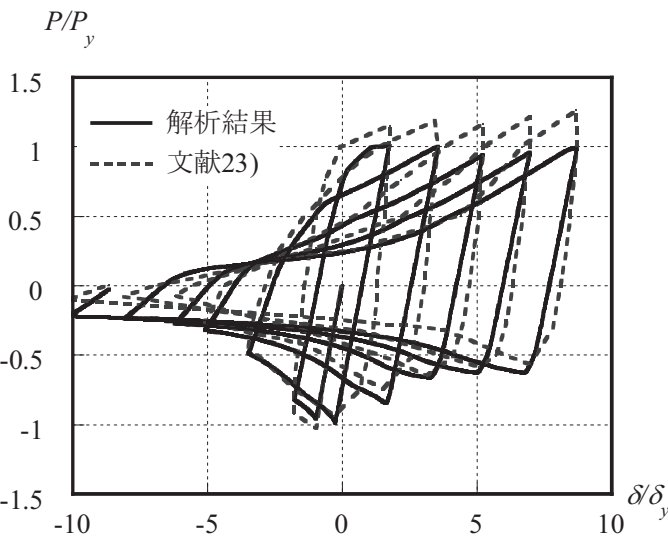

付図 1 繰返し荷重を受ける H 形鋼圧縮部材の荷重-変位関係 